\title{
Evidence for a change in oestradiol negative feedback and LH pulse frequency in post-partum ewes
}

\author{
P. J. Wright*, P. E. Geytenbeek $\dagger$, I. J. Clarke $\ddagger$ and J. K. Findlay $\ddagger$ \\ ${ }^{*}$ Department of Veterinary Clinical Sciences, University of Melbourne, Werribee, Victoria 3030 , \\ $\dagger$ Waite Agricultural Research Institute, Adelaide, South Australia 5064, and \\ $\ddagger$ Medical Research Centre, Prince Henry’s Hospital, Melbourne, Victoria 4003, Australia
}

\begin{abstract}
Summary. Plasma LH levels and the effects of ovariectomy and of chronic and acute administration of oestradiol-17 $\beta$ were compared in post-partum (anoestrous) and cyclic Merino ewes during the breeding season. Plasma $\mathrm{LH}$ and $\mathrm{LH}$ pulses were detected in more post-partum (anoestrous) than cyclic (dioestrous) ewes (10/10 and $4 / 10$ respectively). The post-partum ewes had a greater pulse frequency $(1.8 \pm 0.42$ compared with $0.4 \pm 0.16$ pulses $/ 6 \mathrm{~h})$ and higher plasma LH levels $(1.16 \pm 0.32$ compared with $0.17 \pm 0.05 \mathrm{ng} / \mathrm{ml})$. Ovariectomized post-partum ewes demonstrated fewer LH pulses $(3.8 \pm 0.36$ compared with $5.0 \pm 0.15$ pulses $/ 6 \mathrm{~h})$ than did ovariectomized cyclic ewes. The depression of plasma $\mathrm{LH}$ following acute i.v. injection of $3 \mu \mathrm{g}$ oestradiol-17 $\beta$ was similar $(0.05<P<0.1)$ for the two groups $(80.5 \pm 3.6$ and $66 \cdot 3 \pm 4 \cdot 1 \%)$. At 7 days after ovariectomy and an oestradiol implant more cyclic ewes than post-partum ewes showed detectable plasma LH and $\mathrm{LH}$ pulses (6/10 compared with $1 / 9$ ewes). By $66 \mathrm{~h}$ after implant removal pulse frequency was less in the post-partum ewes $(3.2 \pm 0.55$ compared with $5.5 \pm 0.56$ pulses $/ 6 \mathrm{~h}$ ).

These findings indicate that in post-partum ewes there is an increased inhibitory (negative-feedback) effect of oestradiol on $\mathrm{LH}$ release and a lower intrinsic frequency of pulsatile release of $\mathrm{LH}$. These factors may be causally related to ovarian acyclicity.
\end{abstract}

\section{Introduction}

The endocrine basis of post-partum anoestrus in the ewe is not known, but could involve an impairment of neuroendocrine mechanisms controlling gonadotrophin release. Changes in pituitary responsiveness to LH-RH and the positive feedback effect of oestrogen are not factors limiting normal ovarian acyclicity post partum (Wright, Geytenbeek, Clarke \& Findlay, 1980). Preovulatory growth and development of ovarian follicles may require an increased tonic secretion of LH (Hauger, Karsch \& Foster, 1977; Baird, 1978), and therefore ovarian acyclicity post partum could be due to an alteration in the response of the hypothalamicpituitary system to the negative-feedback effect of oestrogen, similar to that shown for ovariectomized ewes during the anoestrous season (Legan, Karsch \& Foster, 1977). We have therefore examined plasma LH levels in intact, post-partum (anoestrous) and cyclic (dioestrous) ewes and the negative-feedback effect of oestrogen on LH release in ewes ovariectomized during dioestrus or the post-partum period. These experiments were done during the breeding season so that the mechanisms involved in post-partum anoestrus were not confounded with those involved in seasonal anoestrus. 


\section{Materials and Methods}

The experiments were undertaken at Mortlock Experiment Station, near Clare, South Australia, in May 1979. Mature Merino ewes (Bungaree strain) lambing in April (autumn) and cyclic parous ewes from the same flock were studied. Each post-partum ewe suckled 1 lamb and the cyclic ewes had not lambed for at least 9 months. Other endocrine aspects of post-partum ewes in this flock have been reported (Wright et al., 1980). In the three experiments using different groups of ewes from the same flock, LH release was assessed by measuring plasma $\mathrm{LH}$ levels in blood samples $(8 \mathrm{ml})$ taken over $6 \mathrm{~h}$ at 20 -min intervals via jugular venous cannulae. Blood samples were chilled at collection, promptly centrifuged and the plasma stored at $-20^{\circ} \mathrm{C}$ until assay.

Experiment 1. Plasma LH levels were measured in 10 anoestrous ewes on one day between 29 and 31 days post partum and in 10 dioestrous ewes treated with cloprostenol $(125 \mu \mathrm{g}$ i.m., I.C.I.) 13 days previously. Plasma progesterone levels were determined in one sample from each ewe to confirm reproductive status.

Experiment 2. Post-partum (anoestrous) $(\mathrm{N}=10)$ and cyclic $(\mathrm{N}=10)$ ewes were ovariectomized when 21-24 days post partum and in mid-dioestrus, respectively. Blood samples were taken as described above 7 days later. At the end of the 6-h period of blood sampling each ewe received an i.v. injection of $3 \mu \mathrm{g}$ oestradiol-17 $\beta$ (Ikapharm) in $2 \mathrm{ml} \mathrm{10 \%} \mathrm{ethanol-0.154}$ $\mathrm{M}-\mathrm{NaCl}$ solution. Blood samples were taken every $20 \mathrm{~min}$ for a further $4 \mathrm{~h}$. Injection of $2.5 \mu \mathrm{g}$ oestradiol $-17 \beta$ is known to reduce plasma LH levels in ovariectomized ewes by approximately 50\% (Clarke \& Findlay, 1980).

Experiment 3. Post-partum $(\mathrm{N}=9)$ and cyclic $(\mathrm{N}=10)$ ewes were ovariectomized when 20-22 days post partum and in mid-dioestrus (13 days after $125 \mu$ g cloprostenol (I.C.I.) i.m.) respectively, and a Silastic (Dow Corning) implant containing oestradiol-17 $\beta$ (95-105 mg) (Ikapharm) was inserted s.c. (Karsch et al., 1973). These implants result in plasma oestradiol levels of 3-5 pg/ml (Legan et al., 1977). After 7 days, blood samples were taken as described above and the implants were removed. Starting $60 \mathrm{~h}$ after implant removal, blood samples were taken every $20 \mathrm{~min}$ for a further $6 \mathrm{~h}$.

\section{Hormone assays}

Plasma LH levels were measured by the double-antibody radioimmunoassay described by Clarke \& Findlay (1980) using rabbit anti-LH sera, NIH-LH-S18 (biopotency $1.03 \times$ NIHLH-S1) as standard and Papkoff LH (G 3222B) for iodination by the chloramine-T method (Greenwood, Hunter \& Glover, 1963). Hormone concentrations and assay quality control data were calculated using the methods and computer program of Burger, Lee \& Rennie (1972). The study included 8 assays with a mean ( \pm s.e.m.) sensitivity of $68.7( \pm 9.6) \mathrm{pg} /$ tube. Samples were assayed in duplicate. The inter-assay coefficients of variation were $17 \%(4.1 \mathrm{ng} / \mathrm{ml})$ and $24 \%$ $(14.0 \mathrm{ng} / \mathrm{ml})$. The intra-assay coefficient of variation was $<20 \%$ over the range $1 \cdot 2( \pm 0.2)-41.5$ $( \pm 2 \cdot 2) \mathrm{ng} / \mathrm{ml}$.

The radioimmunoassay for progesterone (Hossian, Lee, Clarke \& O'Shea, 1979) had a sensitivity of $0.1 \mathrm{ng} / \mathrm{ml}$. Inter-assay variation was assessed by repeated assay $(n=9)$ of plasma pools from one wether and 2 ewes; the respective values were $<0 \cdot 1,2 \cdot 3 \pm 0 \cdot 29$ and $5 \cdot 3 \pm 0 \cdot 19$ $\mathrm{ng} / \mathrm{ml}$ (mean \pm s.e.m.). The inter-assay coefficient of variation was $<20 \%$ over the range $0 \cdot 2-3.4 \mathrm{ng} / \mathrm{ml}$.

\section{Analysis of results}

Treatment effects were assessed by comparison of plasma $\mathrm{LH}$ levels on an intra-assay basis only. For each ewe the plasma LH levels for the series of blood samples taken over a 
$6 \mathrm{~h}$ period were analysed in terms of mean LH levels and of the frequency and amplitude of short-term elevations of plasma LH that reflected pulsatile discharges (pulses) of the hormone from the pituitary gland. An LH pulse was identified when the plasma concentration in one or a series of samples was at least $1 \mathrm{ng} / \mathrm{ml}$ and greater than the level in preceding and/or following samples by a factor of at least 4 times the coefficient of variation of the assay. Pulse amplitude was the maximum plasma $\mathrm{LH}$ concentration associated with the pulse minus the concentration preceding the pulse. These definitions are similar to those of Baird (1978) and Lincoln (1978). Plasma LH levels less than the sensitivity of the assay were computed as $0 \mathrm{ng} / \mathrm{ml}$. The inhibitory effect of oestradiol given i.v. was expressed as \% fall of the mean plasma LH concentration of samples taken from 1 to $4 \mathrm{~h}$ after treatment compared with the mean concentration of samples taken for $6 \mathrm{~h}$ before treatment (Clarke \& Findlay, 1980).

Between-treatment group comparisons were made on the number of ewes with plasma $\mathrm{LH}$ values above the detection limit of the assay and the number of ewes with LH pulses. Comparisons were also made (group mean \pm s.e.m.) of the frequency and amplitude of plasma $\mathrm{LH}$ pulses, plasma LH levels and \% change in plasma LH level following oestradiol treatment. Standard statistical methods, Student's $t$ test, Behren-Fisher test, Wilcoxon's two sample test and exact tests for independence of a $2 \times 2$ contingency table, were used (Steel \& Torrie, 1960).

\section{Results}

\section{Experiment 1: $L \mathrm{H}$ release in intact ewes}

All the post-partum ewes but only $40 \%$ of the dioestrous ewes had detectable $(>0.3 \mathrm{ng} / \mathrm{ml})$ LH levels. In the post-partum ewes, the mean frequency of $\mathrm{LH}$ pulses and the mean $\mathrm{LH}$ concentrations were greater than in dioestrous ewes (Table 1). Plasma progesterone levels were $<0 \cdot 1$ $\mathrm{ng} / \mathrm{ml}$ in the post-partum ewes and $2.6 \pm 0.4 \mathrm{ng} / \mathrm{ml}$ (mean \pm s.e.m.) in the dioestrous ewes.

Table 1. Plasma LH in intact cyclic (dioestrous) and post-partum (anoestrous) ewes (Exp. 1)

\begin{tabular}{|c|c|c|c|}
\hline & \multicolumn{2}{|c|}{ Reproductive status } & \multirow[b]{2}{*}{ Statistical significance } \\
\hline & Cyclic & Post partum & \\
\hline No. of ewes & 10 & 10 & \\
\hline $\begin{array}{l}\text { No. of ewes with detectable LH } \\
(>0.3 \mathrm{ng} / \mathrm{ml})\end{array}$ & 4 & 10 & \\
\hline No. of ewes with LH pulses & 4 & 10 & $\begin{array}{c}P=0.005 \text { (Exact test of } \\
\text { independence) }\end{array}$ \\
\hline $\begin{array}{l}\text { Frequency of LH pulses } \\
\quad \text { (pulses } / 6 \mathrm{~h} \text { )* }\end{array}$ & $0.4 \pm 0.16$ & $1.8 \pm 0.42$ & $\begin{array}{c}P<0.01 \text { (Wilcoxon's } 2 \text { sample } \\
\text { test) }\end{array}$ \\
\hline LH pulse amplitude (ng/ml)* & $3.7 \pm 0.92$ & $6.0 \pm 0.97$ & $P>0.05(t=1.4)$ \\
\hline LH conc. (ng/ml)* & $0.17 \pm 0.05$ & $1 \cdot 16 \pm 0.32$ & $P<0.05(t=3.1)$ \\
\hline
\end{tabular}

* Mean \pm s.e.m.

\section{Experiment 2: $L \mathrm{H}$ release in ovariectomized ewes given a single oestradiol injection}

At 7 days after ovariectomy, the LH pulse frequency was less in post-partum ewes than in cyclic ewes, but mean plasma levels were similar in the two groups. The depressions of plasma LH levels after oestradiol injection for both groups of ewes were not significantly different (Table 2). 
Table 2. Plasma LH values (mean \pm s.e.m.) in ovariectomized cyclic and post-partum ewes and the effect of a single injection of $3 \mu \mathrm{g}$ oestradiol i.v. (Exp. 2)

\begin{tabular}{|c|c|c|c|}
\hline & \multicolumn{2}{|c|}{ Reproductive status } & \multirow[b]{2}{*}{ Statistical significance } \\
\hline & Cyclic & Post partum & \\
\hline No. of ewes & 10 & 10 & \\
\hline No. of ewes with LH pulses & 10 & 10 & \\
\hline $\begin{array}{l}\text { Frequency of LH pulses } \\
\text { (pulses } / 6 \mathrm{~h})\end{array}$ & $5 \cdot 0 \pm 0 \cdot 15$ & $3 \cdot 8 \pm 0 \cdot 36$ & $P<0.05(t=3.1)$ \\
\hline $\begin{array}{l}\text { LH pulse amplitude (ng/ml) } \\
\text { LH conc. }(\mathrm{ng} / \mathrm{ml})\end{array}$ & $\begin{array}{l}4.6 \pm 0.65 \\
4 \cdot 1 \pm 0.61\end{array}$ & $\begin{array}{l}6.3 \pm 0.44 \\
4.6 \pm 0.40\end{array}$ & $\begin{array}{l}0.05<P<0.1(t=2.0) \\
P>0.05(t=0.7)\end{array}$ \\
\hline $\begin{array}{l}\% \text { fall in plasma LH level after } \\
\text { oestradiol }\end{array}$ & $66 \cdot 3 \pm 4 \cdot 1$ & $80 \cdot 5 \pm 3 \cdot 6$ & $0.05<P<0.1(t=1.8)$ \\
\hline
\end{tabular}

Experiment 3: $L H$ release in ovariectomized ewes treated chronically with oestradiol

After 7 days of oestradiol treatment, a greater proportion of cyclic ewes had detectable LH and LH pulses than did post-partum ewes. During the period $60-66 \mathrm{~h}$ after implant removal, the cyclic ewes had a greater LH pulse frequency (Table 3 ).

Table 3. Plasma LH values (mean \pm s.e.m.) in ovariectomized cyclic and post-partum ewes treated with an oestradiol implant for 7 days (Exp. 3)

\begin{tabular}{|c|c|c|c|}
\hline & \multicolumn{2}{|c|}{ Reproductive status } & \multirow[b]{2}{*}{ Statistical significance } \\
\hline & Cyclic & Post partum & \\
\hline No. of ewes & 10 & 9 & \\
\hline $\begin{array}{l}\text { At time of implant removal } \\
\text { No. of ewes with detectable } \mathrm{LH} \\
(>0.3 \mathrm{ng} / \mathrm{ml})\end{array}$ & 6 & 1 & $P=0.04$ (Exact test of independence) \\
\hline $\begin{array}{l}\text { No. of ewes with } \mathrm{LH} \text { pulses } \\
\text { Frequency of } \mathrm{LH} \text { pulses (pulses } / 6 \mathrm{~h}) \\
\mathrm{LH} \text { pulse amplitude }(\mathrm{ng} / \mathrm{ml}) \\
\mathrm{LH} \text { conc. }(\mathrm{ng} / \mathrm{ml})\end{array}$ & $\begin{array}{c}6 \\
2 \cdot 1 \pm 0.75 \\
1.2 \pm 0.31 \\
0.45 \pm 0.18\end{array}$ & $\begin{array}{c}1 \\
0.4 \pm 0.44 \\
1.20 \\
0.26 \pm 0.25\end{array}$ & $P=0.04$ (Exact test of independence) \\
\hline $\begin{array}{l}60-66 \text { h after implant removal } \\
\text { No. of ewes with detectable } \mathrm{LH} \\
(>0.3 \mathrm{ng} / \mathrm{ml})\end{array}$ & 10 & 9 & \\
\hline $\begin{array}{l}\text { No. of ewes with plasma } \mathrm{LH} \text { pulse } \\
\text { Frequency of } \mathrm{LH} \text { pulses }(\mathrm{pulses} / 6 \mathrm{~h}) \\
\text { Amplitude of } \mathrm{LH} \text { pulses }(\mathrm{ng} / \mathrm{ml}) \\
\mathrm{LH} \text { conc. }(\mathrm{ng} / \mathrm{ml})\end{array}$ & $\begin{array}{c}10 \\
5 \cdot 5 \pm 0.56 \\
3.9 \pm 0.70 \\
3.4 \pm 0.62\end{array}$ & $\begin{array}{l}9 \\
3 \cdot 2 \pm 0 \cdot 55 \\
2 \cdot 9 \pm 0 \cdot 44 \\
1 \cdot 9 \pm 0 \cdot 50\end{array}$ & $\begin{array}{l}P<0.05(t=2.9) \\
P>0.05(t=1.18) \\
0.05<P<0.1(t=1.8)\end{array}$ \\
\hline
\end{tabular}

\section{Discussion}

The frequency of pulsatile release of $\mathrm{LH}$ and the mean plasma $\mathrm{LH}$ levels observed in postpartum anoestrous ewes were greater than in the dioestrous ewes, but were much less than LH levels associated with preovulatory follicular development (Hauger et al., 1977; Baird, 1978), when plasma levels of $2-8.6 \mathrm{ng} / \mathrm{ml}$ and pulse frequencies of greater than $1 / \mathrm{h}$ were detected. The reduced levels of $\mathrm{LH}$ in dioestrous compared with post-partum anoestrous ewes probably reflects the enhancing effect of progesterone on negative feedback of oestradiol in dioestrous ewes (Hauger et al., 1977). The findings for post-partum ewes suggest that ovarian acyclicity could result from inadequate $\mathrm{LH}$ release leading to failure of follicular development. The lower levels of LH in these ewes compared with those associated with preovulatory follicular development could be due to a reduced intrinsic frequency of LH-RH release and/or an increased inhibitory effect of oestradiol-17 $\beta$ on the hypothalamo-pituitary axis. 
If $\mathrm{LH}$ pulse frequency reflects the pulsatile release of $\mathrm{LH}-\mathrm{RH}$ from the hypothalamus (Lincoln \& Short, 1980) our data suggest that there is a lower intrinsic release frequency of LH-RH in post-partum ewes. The LH pulse frequency in ovariectomized post-partum ewes was less than in ovariectomized cyclic ewes and also less than the frequency reported in other studies of ovariectomized ewes (Butler, Malven, Willett \& Bolt, 1972; Reeves, O'Donnell \& Denorscia, 1972; Diekman \& Malven, 1973; Martensz, Baird, Scaramuzzi \& van Look, 1976). A lower frequency of LH pulses was also observed after removal of oestradiol implants in ovariectomized post-partum ewes than in ovariectomized cyclic ewes.

The negative-feedback effect of oestradiol-17 $\beta$ on LH release was greater in ovariectomized post-partum than in ovariectomized cyclic ewes, as shown by the smaller number of post-partum ewes with detectable plasma LH levels 7 days after ovariectomy and chronic oestradiol-17 $\beta$ treatment. These findings were similar to those for ovariectomized ewes in the anoestrous season (Legan et al., 1977). This suggests that both seasonal anoestrus and post-partum anoestrus could involve a suppression of tonic $\mathrm{LH}$ release due to increased inhibition by oestradiol. The lower plasma LH levels in post-partum ewes 60-66 h after implant removal indicated a slower rate of recovery from the inhibitory effects of oestradiol in these ewes. However, this recovery rate was more rapid than that associated with ovarian acyclicity in amenorrhoeic women treated with oestrogen (Santen et al., 1978).

We suggest that ovarian acyclicity in the post-partum ewe could result from a failure of follicular development due to inadequate secretion of $\mathrm{LH}$ and that the lack of $\mathrm{LH}$ release reflects an increased negative feedback of oestradiol-17 $\beta$ and a lower intrinsic frequency of pulsatile release of LH-RH.

We thank Miss N. Colvin, Mrs R. Jenner, Mr F. Hill; and Mr B. Doughton for skilled technical assistance: Mrs L. Magill and Ms J. Volfsbergs for typing; and NIH and Dr $\mathrm{H}$. Papkoff for LH standards. These studies were supported by grants from the Australian Meat Research Committee, the Australian Wool Research Trust Funds and the Ford Foundation.

\section{References}

Baird, D.T. (1978) Pulsatile secretion of LH and ovarian estradiol during the follicular phase of the sheep estrous cycle. Biol. Reprod. 18, 359-364.

Burger, H.G., Lee, V.W.K. \& Rennie, G.C. (1972) A generalised computer program for the treatment of data from competitive protein binding assays including radioimmunoassays. J. Lab. Clin. Med. 80, 302-312.

Butler, W.R., Malven, P.V., Willett, L.B. \& Bolt, D.J. (1972) Patterns of pituitary release and cranial output of LH and prolactin in ovariectomized ewes. Endocrinology 91, 793-801.

Clarke, I.J. \& Findlay, J.K. (1980) Catechol oestrogens and gonadotrophin secretion in the ewe: affinity for pituitary oestrogen receptors in vitro and action on gonadotrophin secretion in vivo. J. Endocr. 85, 503-509.

Diekman, M.A. \& Malven, P.V. (1973) Effect of ovariectomy and estradiol on $\mathrm{LH}$ patterns in ewes. J. Anim. Sci. 37, 562-567.

Greenwood, F.C., Hunter, W.M. \& Glover, J.S. (1963) The preparation of ${ }^{131}$ I-labelled human growth hormone of high specific activity. Biochem. J. 89, $114-123$.
Hauger, R.L., Karsch, F」. \& Foster, D.L. (1977) A new concept for control of the estrous cycle of the ewe based on the temporal relationships between luteinizing hormone, estradiol and progesterone in peripheral serum and evidence that progesterone inhibits tonic LH secretion. Endocrinology 101, 807-817.

Hossian, M.I., Lee, C.S., Clarke, I.J. \& O'Shea, J.D. (1979) Ovarian and luteal blood flow, and peripheral plasma progesterone levels, in cyclic guinea-pigs. J. Reprod. Fert. 57, 167-174.

Karsch, F.J., Dierschke, D.J., Weick, R.F., Yamaji, T., Hotchkiss, J. \& Knobil, E. (1973) Positive and negative feedback control by estrogen of luteinizing hormone secretion in the Rhesus monkey. Endocrinology 92, 799-804.

Legan, S.L., Karsch, FJ. \& Foster, D.L. (1977) The endocrine control of seasonal reproductive function in the ewe: a marked change in response to the negative feedback action of estradiol on luteinizing hormone secretion. Endocrinology 101, $818-824$

Lincoln, G.A. (1978) Hypothalamic control of the testis in the ram. Int. J. Androl. 1, 331-341. 
Lincoln, G.A. \& Short, R.V. (1980) Seasonal breeding; nature's contraceptive. Recent Prog. Horm. Res. (In Press).

Martensz, N.D., Baird, D.T., Scaramuzzi, RJ. van Look, P.F.A. (1976) Androstenedione and the control of luteinizing hormone in the ewe during anoestrus. $J$. Endocr. 69, 227-237.

Reeves, J.J., O'Donnell, D.A. \& Denorscia, F. (1972) Effect of ovariectomy on serum luteinizing hormone (LH) concentrations in the anestrous ewe. J. Anim. Sci. 35, 73-78.

Santen, R.J., Friend, J.N., Trojanowsk, D., Davis, B.,
Samojlik, E. \& Bardin, C.W. (1978) Prolonged negative feedback suppression after estradiol administration: proposed mechanism of eugonadal secondary amenorrhea. J. clin. Endocr. Metab. 47, 1220-1229.

Steel, R.D.G. \& Torrie, J.H. (1960) Principles and Procedures of Statistics. McGraw Hill, New York.

Wright, P.J., Geytenbeek, P.E., Clarke, IJ. \& Findlay, J.K. (1980) Pituitary responsiveness to LH-RH, the occurrence of oestradiol-17ß-induced LH-positive feedback and the resumption of oestrous cycles in ewes post partum. J. Reprod. Fert. 60, 171-176.

Received 28 March 1980 